\title{
FAKTOR-FAKTOR YANG MEMPENGARUHI KEPATUHAN WAJIB PAJAK BUMI DAN BANGUNAN DI KECAMATAN TELUK SEGARA KOTA BENGKULU
}

\author{
Yennita Asriyani \\ Karona Cahya Susena \\ Fakultas Ekonomi Universitas Dehasen Bengkulu \\ karona cs@yahoo.co.uk
}

\begin{abstract}
ABSTRAK
Yennita Asriyani dan Karona Cahya Susena; penelitian ini bertujuan untuk mengetahui faktor-faktor yang mempengaruhi kepatuhan wajib pajak Bumi dan Bangunan di Kecamatan Teluk Segara Kota Bengkulu. Metode yang digunakan dalam penelitian ini adalah penelitian kuantitatif, dengan menggunakan kuesioner sebagai instrumen yang tersebar ke 91 pajak bumi dan bangunan pedesaan dan perkotaan, wajib pajak di kecamatan Teluk Segara. menganalisis data dalam penelitian ini menggunakan skala penilaian dan analisis skala likert. Hasil penelitian ini menunjukkan bahwa salah satu indikator, yaitu wajib pajak pengetahuan, memperoleh skor tertinggi adalah 367. Ini berarti bahwa indikator dapat mempengaruhi pembayar pajak ketaatan, tapi itu bukan faktor yang mampu membuat wajib pajak patuh membayar pajak tanah dan bangunan karena alasan kepentingan pribadi. Indikator yang memperoleh nilai terendah adalah 171 adalah tingkat pendapatan yang berarti itu tidak bisa mempengaruhi pembayar pajak ketaatan karena tingkat pajak bumi dan bangunan relatif murah dan dapat dicapai oleh mereka untuk membayar.
\end{abstract}

\begin{abstract}
Yennita Asriyani dan Karona Cahya Susena; Land and building tax was one of taxes which was potentially to be explored as revenue source. Tax revenue was really determined from taxpayers obedience in running their responsibility in tax field. This researchwas aimed at explaining the effect of income rate, taxpayer knowledge, Service Quality, Taxpayers Awareness, and Tax Punishment in influencing tax payers obedience in paying rural and urbam land and building tax. The study was located at Teluk Segars district in Bengkulu city. The method used in this research was quantitative research, by using questionnaire as the instrument which was spread out to 91 rural and urban land and building tax, tax payers at Teluk Segara district. Data analyzing in this study used rating scale and likert scale analysis. The result of this research showed that one of indicators, namely taxpayers knowledge, gained the highest score is 367 . It meant that the indicator could influence taxpayers obedience, but it was not the factor that was able to make taxpayers obedient to pay land and building tax because of private interest reason. The indicator which gained the lowest score is 171 was income rate which meant it could not influence taxpayers obedience because land and building tax rate was relatively cheap and achievable by them to pay.
\end{abstract}

Key Words: Income Rate, Taxpayer Knowledge, Service Quality, Taxpayer Awareness, Tax Punishment, Taxpayer Compliance

\section{PENDAHULUAN}

Menurut Peraturan Menteri Dalam Negeri Nomor 21 Tahun 2011 tentang Perubahan kedua atas Peraturan Menteri Dalam Negeri Nomor 13 Tahun 2006 tentang pedoman pengelolaan keuangan daerah, Keuangan Daerah adalah semua hak dan kewajiban daerah dalam rangka penyelenggaraan pemerintahan daerah yang dapat dinilai dengan uang termasuk didalamnya segala bentuk kekayaan yang berhubungan dengan hak dan kewajiban. Sementara pengelolaan keuangan daerah adalah keseluruhan kegiatan yang meliputi perencanaan, pelaksanaan, penatausahaan, pelaporan, pertanggung jawaban, dan pengawasan keuangan daerah tersebut. Pemegang Kekuasaan Pengelolaan Keuangan Daerah adalah kepala daerah yang karena jabatannya mempunyai kewenangan menyele-nggarakan keseluruhan pengelolaan keuangan daerah.

Pendapatan Asli Daerah (PAD) merupakan pendapatan daerah yang ber-sumber dari hasil pajak daerah, hasil retribusi Daerah, hasil pengelolaan kekayaan daerah yang dipisahkan, dan lain-lain pendapatan asli daerah yang sah, yang bertujuan untuk memberikan keleluasaan kepada daerah dalam menggali pendanaan dalam pelaksanaan otonomi daerah sebagai mewujudkan asas desentralisasi.

Hak dan kewajiban daerah tersebut perlu dikelola dalam suatu sistem pengelolaan keuangan daerah. Pengelolaan keuangan daerah merupakan sub- sistem dari sistem pengelolaan keuangan Negara 
dan merupakan elemen pokok dalam penyelenggaraan pemerintah daerah. Pengelolaan keuangan daerah juga harus dilakukan dengan cara yang baik dan bijak agar keuangan daerah tersebut bisa menjadi efisien penggunaanya yang sesuai dengan kebutuhan daerah.

Berdasarkan UU No. 28 Tahun 2009 tentang Pajak Daerah dan Retribusi Daerah, PBB yang semula merupakan pajak pusat saat ini telah dilimpahkan ke kabupaten/kota menjadi pajak daerah. Terhitung tanggal 1 Januari 2014, semua kabupaten/ kota wajib mengelola pajak bumi dan bangunan perdesaan dan perkotaan (PBB-P2). Sehingga daerah memiliki tanggung jawab penuh guna mengelola pajak bumi dan bangunan perdesaan dan perkotaan. Sekarang yang mengelola pajak bumi dan bangunan bukan Kantor Pelayan Pajak Pratama tetapi Dinas Pendapatan Pengelolaan Keuangan dan Aset.

Dari Undang-undang tersebut banyak sekali perubahan-perubahan yang terjadi di dalam sektor pajak, salah satunya menurunnya kesadaran Wajib Pajak di dalam hal pembayaran pajak. Apalagi kondisi perekonomian kita yang tidak menentu yang membuat menurunnya Anggaran Pendapatan Belanja Negara (APBN).Untuk mengatasi masalah menurunnya kesadaran wajib pajak tersebut, pemerintah membuat perencanaan-perencanaan, baik perencanaan jangka panja- ng maupun perencanaan jangka pendek, agar semua itu bisa tercapai yaitu mulai dari kesadaran masyarakat sebagai wajib pajak untuk melaksanakan tugas dan kewajibannya sebagai wajib pajak. Kesadaran masyarakat dibidang pajak adalah hal yang sangat penting dikarenakan segala sesuatu yang terjadi di dalam sebuah negara masyarakatlah yang memulai untuk kemajuan sebuah negara. Dan masya-rakat patuh dalam melakukan kewajibannya adalah salah satu kepatuhan terhadap hukum.

Untuk menjadikan masyarakat yang patuh terhadap kepatuhan wajib pajak perlu diadakan pembinaan terhadap wajib pajak, banyak wajib pajak yang belum mengerti masalah kegunaan pajak. Bahwa pembayaran pajak yang mereka lakukan bukanlah merupakan salah mengeluarkan uang secara cuma-cuma, akan tetapi mereka harus menyadari bahwa pembayaran pajak yang mereka lakukan adalah sebagian digunakan untuk pembangunan jalan, jembatan dan fasilitas lainya yang mereka nikmati setiap hari.

Dalam hal pembayaran pajak seharusnya masyarakat merasa malu jika tidak membayar pajak sesuai dengan peraturan yang berlaku, karena semua yang mereka keluarkan itu adalah semata-mata demi kebaikan bersama dan itu akan dinikmati selamanya. Oleh sebab itu kesadaran dan kepatuhan wajib pajak masyarakat sebagai wajib pajak untuk selalu melakukan kewajibannya adalah salah satu faktor yang membantu dan mendukung roda pemerintahan dalam membangun dan menciptakan negara Indonesia yang adil dan makmur seperti yang kita inginkan. Penelitian ini di lakukan di Kecamatan Teluk Segara Kota Bengkulu, dan untuk mempermudah dalam penelitian ini pengambilan sampel ditujukan pada Kelurahan Malabero.

\section{LANDASAN TEORI}

Pajak

Definisi pajak menurut Feldmann (Wirawan, 2008: 5) "Pajak adalah prestasi yang di paksakan sepihak oleh terutang kepada penguasa (menurut norma-norma yang ditetapkannya secara umum), tanpa adanya kontra-prestasi dan semata-mata di gunakan untuk menutup pengeluaran-pengeluran umum".

Definisi pajak menurut Prof. Dr. P.J.A. Adrianai (Pandiangan, 2014:3) “ Pajak adalah iuran kepada negara (yang dapat dipakasakan) yang terutang oleh yang wajib membayarnya menurut peraturanperaturan, dengan tidak mendapat prestasi-kembali, yang langsung dapat ditunjuk, dan yang gunanya adalah untuk membiayai pengeluaran-pengeluaran umum terkait dengan tugas negara untuk menyelenggarakan pemerintah".

Sedangkan menurut Prof. Dr .H.Rochmat Soemitro.,S.H. (Widyaningsih, 2013:2) mengemukakan definisi pajak sebagai "Pera-lihan kekayaan dari pihak rakyat kepada kas negara untuk membiayai pengeluaran rutin dan surplusnya digunakan untuk public saving yang merupakan sumber utama untuk membiayai public investmen".

Lebih lanjut, menurut Dr. Soeparman Soemohamijaya (Diana,2013:35) yaitu "Pajak adalah iuran wajib berupa uang atau barang yang dipungut oleh penguasa berdasarkan norma - norma hukum guna menutup biaya produksi barang-barang dan jasa kolektif dalam men-capai kesejahteraan umum".

Definisi pajak menurut Fidel (2010: 4) yaitu "Pajak adalah harta kekayaan yang berdasarkan undang-undang, atas penghasilannya tersebut, maka sebagian wajib diberikan rakyat kepada negara tanpa mendapat kontraprestasi".

Dari pengertian - pengertian tersebut, maka dapat diambil ke-simpulan bahwa pajak merupakan iuran wajib yang bersifat memaksa masyarakat melalui proses peralihan kekayaan kepada pemerintah untuk membiayai pengeluaran rutin negara dengan imbalan secara tidak langsung. 
Sedangkan Pajak Daerah adalah iuran wajib yang dilakukan oleh orang pribadi atau badan kepada daerah tanpa imbalan langsung yang seimbang, yang dapat di paksakan berdasarkan peraturan perundang-undangan yang berlaku, yang digunakan untuk membiayai penyelenggaraan pemerintah daerah dan pembangunan daerah.

Secara garis besar ciri-ciri yang terdapat pada pajak adalah sebagai berikut :

1. Pemungutan pajak dapat dipaksakan karena didasarkan atas undang-undang.

2. Pihak yang membayar pajak tidak mendapat kontra prestasi langsung.

3. Pajak dipungut oleh negara, baik oleh pemerintah pusat maupun pemerintah daerah.

4. Pajak digunakan untuk membiayai pengeluaran - pengeluaran pemerintah, di mana jika terjadi kelebihan maka akan diperguna-kan untuk mebiayai public investment.

5. Pajak dapat pula membiayai tujuan yang tidak budgeter, yaitu fungsi mengatur.

\section{Fungsi Pajak}

Pajak mempunyai peranan yang sangat penting dalam kehidupan bernegara, khususnya sebagai sumber pembiayaan dan pembangunan negara. Sebagaimana telah diketahui ciri-ciri yang melekat pada pengertian pajak dari berbagai definisi, maka pajak mempunyai beberapa fungsi (Widyaningsih, 2013: 3) yaitu :

1. Fungsi Penerimaan (budgeter)

Pajak berfungsi sebagai sumber dana yang diperuntukkan bagi pengeluaran-pengeluaran pemerintah. Dalam APBN, pajak merupakan sumber penerimaan dalam negeri.

2. Fungsi Mengatur (regulator)

Pajak berfungsi sebagai alat untuk mengatur atau melaksanakan kebijakan di bidang sosial dan ekonomi. Misalnya PPnBM untuk barang-barang mewah, hal ini diterapkan pemerintah dalam upaya mengatur agar tingkat konsumsi barang-barang mewah dapat dikendalikan.

3. Fungsi Stabilitas

Fungsi ini berhubungan dengan kebijakan untuk menjaga stabilitas harga (melalui dana yang diperoleh dari pajak) sehingga laju inflasi dapat dikendalikan.

4. Fungsi Redistribusi

Dalam fungsi redistribusi, lebih ditekankan unsur pemerataan dan keadilan dalam masyarakat. Fungsi ini terlihat dari adanya lapisan tarif dalam pengenaan pajak. Contohnya dalam pajak penghasilan, semakin besar jumlah penghasilan maka akan semakin besar pula jumlah pajak yang terutang.

5. Fungsi Demokrasi

Pajak dalam fungsi demokrasi merupakan wujud sistem gotong-royong. Fungsi ini dikaitkan dengan tingkat pelayanan pemerintah kepada masyarakat pembayar pajak.

\section{Jenis Pajak}

Pajak dapat dikelompokkan menjadi 3golongan (Diana, 2013: 43) sebagai berikut:

1. Menurut Sifatnya

a. Pajak Subyektif, yaitu pajak yang erat kaitannya atau hubungannya dengan subjek pajak atau yang dikenakan pajak dan besarnya dipengaruhi oleh keadaan wajib pajak. Pajak ini disebut juga pajak langsung, Contoh: Pajak Penghasilan.

b. Pajak Objektif, yaitu pajak yang erat hubungannya dengan obyek pajak, yang selain dari pada benda dapat pula berupa keadaan, perbuatan atau peristiwa yang menyebabkan timbulnya kewajiban membayar. Pajak ini disebut juga pajak tidak langsung, Contoh: Pajak Pertambahan Nilai.

2. Menurut Pembebanannya

a. Pajak Langsung, yaitu pajak yang langsung dibayar atau dipikul oleh wajib pajak yang bersangkutan dan pajak ini langsung dipungut pemerintah dari wajib pajak, tidak dapat dilimpahkan ke orang lain dan dipungut secara berkala. Contohnya: PPh dan PBB

b. Pajak Tidak Langsung, yaitu pajak yang dipungut kalau ada suatu peristiwa atau perbuatan tertentu, seperti penggerakan barang tidak bergerak, pembuatan akte dan lain-lain. Pembayaran pajak dapatmelimpahkan beban pajaknya kepada pihak lain serta pajak ini tidak mempergunakan surat ketetapan pajak.

Contoh: PPN dan PPnBM, Bea Materai.

3. Menurut Kewenangannya

a. Pajak Pusat, yaitu pajak yang wewenang pemungutannya atau dikelola oleh Pemerintah Pusat dan hasilnya dipergunakan untuk membiayai pengeluaran rutin negara dan pembanguan (APBN).

Contoh: PPh, PPN dan PPnBM, PBB dan Bea Materai 
b. Pajak Daerah, yaitu pajak yang wewenang pemungutannya atau dikelola oleh Pemerintah Daerah dan hasilnya dipergunakan untuk membiayai pengeluaran rutin dan pembangunan daerah.

Contoh: Pajak Hotel, Pajak Restoran, Pajak Reklame, Pajak Kendaraan Bermotor.

\section{Tata Cara Pemungutan Pajak}

\section{Stelsel Riil}

Cara pemungutan pajak dapat dilakukan berdasarkan tiga stelsel (Diana, 2013: 76), yaitu:

Besarnya pajak yang dipungut berdasarkan penghasilan nyata yang diperoleh oleh wajib pajak untuk masa yang bersangkut. Jadi pemungutan pajak baru dapat dilaksankan setelah ahir tahun takwim (periode) setelah mengetahui penghasilan yang sesungguhnya yang diperoleh pada tahun sekarang.

2. Stelsel Fiktif

Besarnya pajak yang dipungut berdasarkan perkiraan besarnya pajak yang terutang untuk dikenakan kepada wajib pajak. Jadi pemungutan dapat dilakukan pada awal tahun pajak. Perkiraan ini dapat menggunakan perbandingan data antara penerimaan /pendapatan wajib pajak pada tahun sebelumnya yang dianggap sama dengan pendapatan yang akan diperoleh pada tahun sekarang.

3. Stelsel Campuran

Besarnya pajak yang dipungut pada awal tahun berdasarkan surat ketetapan pajak sementara yang dikeluarkan pada awal tahun yang berhitungan awalnya berdasarkan stelsel fiktif (perkiraan). Untuk mengetahui besarnya pajak yang sesungguhnya maka pada akhir tahun diterapkan perhitungan berdasarkan stelsel rill (nyata), sehingga ketetapan jumlah pajak yang terutang dapat dikoreksi dengan stelsel ini atau disesuaikan dengan pajak yang sebenarnya.

\section{Pajak Bumi Dan Bangunan (PBB)}

Pajak Bumi dan Bangunan berdasarkan UU Republik Indonesia No. 28 tahun 2009 (2010:14) ditetapkan menjadi Pajak Bumi dan Bangunan Perdesaan dan Perkotaan.Pajak Bumi dan Bangunan Perdesaan dan Perkotaan merupakan pajak atas bumi dan / atau bangunan yang dimiliki, dikuasai dan dimanfaatkan oleh orang pribadi atau badan kecuali kawasan yang digunakan untuk kegiatan usaha perkebunan, perhutananan dan pertambangan. Pajak Bumi dan Bangunan Perdesaan dan Perkotaan ini dipungut oleh pemerintah daerah berdasarkan UU No. 28 tahun 2009 (Yusnindar: 2015).

Definisi Pajak Bumi dan Bangunan menurut Widyaningsih (2013: 190) "PBB adalah pajak yang bersifat kebendaan dalam arti besarnya pajak terutang ditentukan oleh keadaan obyek yaitu bumi /tanah dan atau bangunan. Sedangkan keadaan subjek yang membayar pajak tidak ikut menentukan pengenaan pajak terutang, karena itu Pajak Bumi dan Bangunan disebut pajak objektif.

Pengertian Pajak Bumi dan Bangunan menurut Mardiasmo (2006: 295), yaitu: "Bumi adalah permukaan bumi dan tubuh bumi yang ada di bawahnya. Permukaan bumi meliputi tanah dan perairan pedalaman (termasuk rawa-rawa tambak perairan) serta laut wilayah Republik Indonesia.

Bangunan adalah konstruksi teknik yang ditanam atau dilekatkan secara tetap pada tanah dan atau perairan untuk tempat tinggal, tempat usaha dan tempat yang diusahakan".

Objek Pajak Bumi dan Bangunan adalah bumi dan atau bangunan. Yang termasuk dalam Bangunan yang dapat dikenakan pajak (Diana, 2013: 123), adalah:

1. Bangunan tempat tinggal (rumah)

2. Gedung kantor

3. Hotel

4. Pabrik

5. Jalan tol

6. Kolam renang

7. Tempat penampungan/ kilang minyak, air dan gas, pipa minyak

8. Serta fasilitas lain yang memberikan mafaat.

Subjek pajak adalah orang pribadi atau badan yang secara nyata (Agus, 2006: 127):

1. Mempunyai suatu hak atas bumi, dan atau;

2. Memperoleh manfaat atas bumi, dan atau;

3. Memiliki bangunan, dan atau;

4. Menguasai bangunan, dan atau;

5. Memperoleh manfaat atas bangunan.

Objek pajak yang tidak dikenakan PBB adalah obyek pajak yang (Diana, 2013: 123):

1. Digunakan semata-mata untuk kepentingan umum dibidang ibadah, sosial, kesehatan, pendidikan dan kebudayaan nasional yang tidak dimaksudkan untuk memperoleh keuntungan seperti, masjid, gereja, rumah sakit pemerintah, sekolah, panti asuhan, dan lain-lain.

2. Digunakan untuk kuburan, peninggalan purbakala atau yang sejenis dengan itu. 
3. Merupakan hutan lindung, suaka alam, hutan wisata, taman nasional dan tanah negara yang belum dibebani oleh hak.

4. Digunakan oleh perwakilan diplomatik berdasarkan asas perlakuan timbal balik.

5. Digunakan oleh badan dan perwakikan organisasi internasional yang ditentukan oleh Menteri Keuangan.

Pendaftaran obyek PBB dilakukan oleh subjek pajak dengan cara mengambil dan mengisi formulir SPOP (Surat Pemberitahuan Objek Pajak) secara jelas, benar dan lengkap serta ditandatangani dan dikembalikan ke Kantor Dinas Pendapatan Pengelolaan Keuangan dan Asetatau tempat yang ditunjuk untuk pengambilan dan pengembalian SPOP (Surat Pemberitahuan Objek Pajak) dengan dilampiri buktibukti pendukung (Diana, 2013: 124), seperti:

1. Sketsa/denah obyek pajak;

2. Fotokopi KTP dan NPWP;

3. Fotocoy sertifikat tanah;

4. Fotocopy akta jual beli;

5. Atau bukti pendukung lainnya

Formulir SPOP disediakan dan dapat diambil gratis di kantor pelayanan PBB atau tempat lain yang ditunjuk atau melalui teknologi internet dengan mencetak langsung dari www.pajak.go.id.

Pendataan dilaksankan oleh Dinas Pendapatan Pengelolaan Keuangan dan Aset dengan menggunakan formulir SPOP dan dilakukan sekurang-kurangnya untuk satu wilayah administrasi desa/ kelurahan. Pendataan dapat dilakukan dengan cara:

1. Penyampaian dan pemantauan pengembalian SPOP

Dapat dilaksanakan pada daerah yang umumnya tidak mempunyai peta, daerah terpencil atau potensi PBB relatif kecil.

2. Identifikasi Obyek Pajak

Dapat dilaksanakan pada daerah yang sudah mempunyai peta yang dapat menentukan posisi relatif OP dan tidak mempunyai data administrasi PBB tiga tahun terakhir secara lengkap.

3. Verifikasi Obyek Pajak

Dapat dilaksanakan pada daerah yang sudah mempunyai peta yang dapat menentukan posisi relatif OP dan mempunyai data administrasi PBB tiga tahun terakhir secara lengkap

4. Pengukuran Bidang Obyek Pajak

Dapat dilaksanakan pada daerah yang sudah mempunyai peta tetapi tidak dapat menentukan posisi relatif $\mathrm{OP}$

Dasar Pengenaan Pajak Bumi dan Bangunan dalah "Nilai Jual Objek Pajak (NJOP)". NJOP ditetapkan perwilayah berdasarkan keputusan Menteri Keuangan dengan mendengar pertimbangan Bupati/ Walikota serta memperhatikan (Diana, 2013: 126):

1. Harga rata-rata yang diperoleh dari transaksi jual beli yang terjadi secara wajar;

2. Perbandingan harga dengan objek lain yang sejenis yang letaknya berdekatan dan fungsinya sama dan telah diketahui harga jualnya;

3. Nilai perolehan baru;

4. Penentuan nilai jual Objek pajak pengganti

Pada dasarnya penetapan NJOP adalah 3 tahun sekali. Namun demikian untuk daerah tertentu yang karena perkembangan pembangunan mengakibatkan kenaikan nilai jual objek pajak cukup besar, maka penetapan nilai jual ditetapkan setahun sekali. Dalam menetapkan nilai jual, Menteri Keuangan mendengar pertimbangan Gubernur serta memperhatikan asas "self-assessment".

Tarif pajak Bumi dan Bangunan untuk perdesaan dan perkotaan diturunkan dari 0,5\% terhadap nilai jual objek pajak (NJOP) menjadi paling tinggi 0,3 \% dari NJOP (Diana, 2013: 126).

Perubahan tarif PBB perdesaan dan perkotaan itu ditetapkan dalam Undang-Undang Nomor 28 tahun 2009 tentang pajak daerah dan retribusi daerah yang selesai di amandemen pada 15 September 2009.

Langkah ini diharapkan dapat memperluas basis pemungutan PBB. Kewenangan penetapan tarif PBB akan dialihkan dari pemerintah pusat kepada pemerintah kabupaten/ kota setelah 31 Desember 2013.

\section{Sistem Pemungutan Pajak}

Sistem pemungutan pajak dapat dibagi menjadi 3 (tiga) jenis (Widyaningsih, 2013: 14), yaitu:

1. Official Assessment System

Sistem ini merupakan sistem pemungutan pajak yang memberi wewenang kepada pemerintah untuk menentukan besarnya pajak yang terutang.

Ciri-ciri Official Assessment System: 
a. Wewenang untuk menentukan besarnya pajak terutang berada pada pemerintah.

b. Wajib pajak bersifat pasif

c. Utang pajak timbul setelah dikeluarkan surat ketetapan pajak oleh pemerintah.

2. Self Assesment System

Sistem pemungutan pajak yang memberikan kepercayaan dan tanggung jawab kepada wajib pajak untuk menghitung, memperhitungkan, menyetor dan melaporkan sendiri pajak terutang. Sistem ini memberikan peluang kepada wajib pajak untuk jujur dan bertanggung jawab akan kewajiban pajaknya. Petugas perpajakan hanya berfungsi sebagai pembina dan pengawas pelaksanaan kewajiban perpajakan wajib pajak.

3. Withholding System

Sistem ini merupakan sistem pemungutan pajak memberi wewenang kepada pihak ketiga untuk memotong atau memungut besarnya pajak yang terutang oleh wajib pajak.

\section{Kepatuhan Wajib Pajak}

Dalam kamus Besar Bahasa Indonesia, yang dimaksud dengan patuh adalah taat pada aturan. Jadi kepatuhan adalah ketaatan dalam menjalankan aturan-aturan yang telah ditetapkan. Selain itu terdapat beberapa pengertian kepatuhan dalam bidang perpajakan menurut para ahli, yaitu:

Menurut Nurmantu (2010:148) dijelaskan bahwa terdapat dua macam kepatuhan yaitu:

1. Kepatuhan Formal

Kepatuhan formal adalah suatu keadaan dimana Wajib Pajak memenuhi kewajiban perpajakan secara formal sesuai dengan ketentuan dalam Undang-Undang Perpajakan. Dalam hal ini kepatuhan formal meliputi:

a. Wajib Pajak membayar pajak dengan tepat waktu.

b. Wajib Pajak membayar pajak dengan tepat jumlah.

c. Wajib pajak tidak memiliki tanggungan Pajak Bumi dan Bangunan.

2. Kepatuhan Material

Kepatuhan material adalah dimana suatu keadaan dimana Wajib Pajak secara subtansi/hakekat memenuhi semua ketentuan perpajakan, yakni sesuai dengan isi dan jiwa undang-undang perpajakan. Pengertian kepatuhan materiil dalam hal ini adalah:

a. Wajib pajak bersedia melaporkan informasi tentang pajakapabila petugas membutuhkan informasi.

b. Wajib pajak berikap kooperatif (tidak menyusahkan) petugas pajak dalam pelaksanaan proses administrasi perpajakan.

c. Wajib pajak berkeyakinan bahwa melaksanakan kewajiban perpajakan merupakan tindakan sebagai warga negara yang baik.

Dari beberapa pengertian diatas dapat ditarik kesimpulan, pengertian kepatuhan wajib pajak adalah wajib pajak yang taat dan memenuhi serta mekaksanakan kewajiban perpajakan sesuai dengan ketentuan perundang-undangan perpajakan.

\section{Faktor-Faktor Yang Mempengaruhi Kepatuhan Wajib Pajak}

Ada beberapa faktor-faktor yang mempengaruhi kepatuhan wajib pajak antara lain menurut Yusnindar (2015:3) yaitu:

1. Kesadaran Wajib Pajak

Kesadaran wajib pajak dalam membayar kewajiban pajak akan meningkat bilamana dalam masyarakat muncul persepsi positif terhadap pajak. Meningkatnya pengetahuan perpajakan masyarakat melalui pendidikan perpajakan baik formal maupun non formal akan berdampak positif terhadap kesadaran wajib pajakuntuk membayar pajak. Karakteristik wajib pajak yang dicerminkan oleh kondisi budaya, sosial dan ekonomi akan dominan membentuk perilaku wajib pajak yang tergambar dalam tingkat kesadaran mereka dalam membayar pajak. Penyuluhan pajak yang dilakukan secara intensif dan kontinyu akan dapat meningkatkan pemahaman wajib pajak tentang kewajiban membayar pajak sebagai wujud kegotong royongan nasional dalam menghimpun dana untuk kepentingan pembiayaan pemerintahan dan pembangunan nasional .

2. Pengetahuan Wajib Pajak

Konsep Pengetahuan pajak yaitu wajib pajak harus meliputi pengetahuan mengenai Ketentuan Umum dan Tata Cara Perpajakan, pengetahuan mengenai Sistem Perpajakan di Indonesia dan pengetahuan mengenai fungsi perpajakan.Dalam penelitian ini yang dimaksud pengetahuan pajak antara lain adalah sejauh mana wajib pajak mengetahui fungsi PBB-P2 sebagai sebagai salah satu sumber pendapatan di Kota Bengkulu, terlebih lagi dengan adanya UU no 28 tahun 2009 mengenai pengelolaan PBB-P2 dari pusat ke daerah menjadi $100 \%$ penerimaan daerah berpotensi menjadi 
sumber pendapatan yang sangat signifikan bagi daerah. Selain pengetahuan tentang fungsi dan kewajiban serta hak wajib pajak mekanisme tata cara pembayaran pajak terutang ke petugas bank yang telah ditunjuk akan membantu kepatuhan wajib pajak dalam membayar pajak. Pengetahuan pajak sendiri pada umumnya terkait dalam tingkat pendidikan seseorang, orang yang memiliki pengetahuan perpajakan lebih tinggi akan memiliki kepatuhan lebih tinggi karena selain mereka tarif pajak yang dibebankan kepada mereka, mereka juga mengetahui bahwa jika mereka tidak melaksanakan kewajiban mereka sebagai wajib pajak mereka akan terkena sanksi atapun denda. Pengetahuan perpajakan yang Wajib Pajak miliki akan membuat mereka mengetahui alur uang pembayaran pajak serta manfaat pajak yang akan mereka dapatkan.

3. Kualitas Pelayanan

Berdasarkan Keputusan Menteri Pendayagunaan Aparatur Negara 63/KEP/M.PAN/7/2003 tentang Pedoman Penyelenggaraan Pelayanan Publik, mengharuskan setiap penyelenggaraan pelayanan publik memiliki standar pelayanan yang dipublikasikan sebagai jaminan adanya kepastian bagi penerima pelayanan termasuk pelayanan perpajakan. Kualitas pelayanan perpajakan dalam Pajak Bumi dan Bangunan Perdesaan dan Perkotaan berdasarkan definisi diatas dapat disimpulkan menjadi dua bagian, yaitu:

a) Metode Penyampaian SPPT

Mekanisme penyerahan SPPT dari Dinas Pendapatan dan Pengelolaan Aset Daerah yang disalurkan kepada kantor kelurahan sesuai domisili Wajib Pajak, dari kantor kelurahan SPPT diserahkan kepada ketua RW yang kemudian oleh ketua RW disampaikan kepada Ketua RT untuk disampaikan kepada wajib pajak.

b) Pelayanan pembayaran PBB-P2

Pelayanan pembayaran PBB-P2 disini adalah mekanisme pembayaran yang dibuat sesederhana mungkin, wajib pajak hanya perlu membawa sejumlah nominal pajak terutangnya beserta SPPT PBB-P2 jika membayar di kelurahan, jika membayar di bank wajib pajak akan dibantu oleh petugas bank. Selain itu fasilitas-fasilitas yang mendukung prosespembayaran yang meningkatkan kenyamanan Wajib Pajak dalam membayar PBB-P2 harus lebih ditingkatkan serta lokasi pembayaran yang cukup mudah di jangkau oleh Wajib Pajak yang ingin membayar juga merupakan bagian dari pelayanan.

4. Tingkat Penghasilan

Tingkat Penghasilan akan mempengaruhi kepatuhan wajib pajak dalam membayar pajak tepat pada waktunya. Kemampuan Wajib Pajak dalam memenuhi kewajiban pajak terkait erat dengan bersama penghasilan, maka salah satu hal yang di pertimbangkan dalam pemungutan pajak adalah penghasilan.

5. Persepsi wajib pajak terhadap sanksi

Sanksi pajak merupakan salah satu faktor yang mempengaruhi kepatuhan wajib pajak, karena fungsi sanksi adalah digunakan sebagai cara untuk mengatur sekelompok populasi untuk memenuhi aturan yang ditentukan. Sanksi ditujukan kepada wajib pajak yang tidak mematuhi aturan perpajakan atau melakukan pelanggaran berupa kecurangan terhadap peraturan perpajakan yang berlaku saat ini. Dengan adanya sanksi berupa denda maupun pidana yang cukup tinggi diharapkan wajib pajak lebih patuh terutama dalam hal membayar PBB. Sanksi perpajakan terjadi karena terdapat pelanggaran terhadap peraturan perundang-undangan perpajakan. Sehingga apabila terjadi pelanggaran maka wajib pajak dihukum dengan indikasi kebijakan perpajakan dan undang-undang perpajakan.Dalam undang-undang perpajakan dikenal dua macam sanksi, yaitu sanksi administrasi dan sanksi pidana. Sanksi administrasi dikenakan tehadap wajib pajak yang tidak memenuhi ketentuan peraturan perpajakan atau melakukan pelanggaran terhadap peraturan perpajakan yang berlaku, sanksi administrasi berupa pembayaran kerugian pada negara, dapat berupa bunga, denda, atau kenaikan.

\section{KERANGKA ANALISIS}

Faktor- faktor yang mempengaruhi tingkat kepatuhan
wajib pajak:
1. Kesadaran Wajib Pajak
2. Pengetahuan Wajib Pajak
3. Kualitas Pelayanan
4. Tingkat Penghasilan
5. Persepsi Wajib Pajak terhadap sanksi

Gambar 1. Kerangka Analisis 


\section{METODOLOGI}

Penelitian ini merupakan penelitian Deskriptif maksudnya memberikan gambaran tentang tingkat kepatuan wajib pajak bumi dan bangunan di Kecamatan Teluk Segara Kota Bengkulu. Populasi yang ada di Kelurahan Malabero Kecamatan Teluk Segara berjumlah 1.023 orang wajib pajak .Sampel yang digunakan dalam penelitian ini berjumlah 91 responden Dengan menggunakan rumus slovin yang diambil secara acak yang dilakukan di Kelurahan Malabero.

Dalam menganalisis data dalam penelitian inimaka penulis menggunakan metode rating scale, setelah data yang diperoleh ditabulasikan. Rating Scale sendiri merupakan distribusi rata-rata kecenderungan persepsi masyarakat terhadap faktor-faktor yang mempengaruhi tingkat kepatuan wajib pajak bumi dan bangunan di Kecamatan Teluk Segara Kota Bengkulu.

Jumlah skor ideal untuk seluruh item (Sugiyono, 2013 : 135), sebagi berikut:

a. Jika semua responden menjawab SS, maka 5 dikalikan dengan jumlah responden.

b. Jika semua responden menjawab ST, maka 4 dikalikan dengan jumlah responden.

c. Jika semua responden menjawab RG, maka 3 dikalikan dengan jumlah responden.

d. Jika semua responden menjawab TS, maka 2 dikalikan dengan jumlah responden.

e. Jika semua responden menjawab STS, maka 1 dikalikan dengan jumlah responden.

Jumlah skor kriterium (apabila setiap butir mendapat skor tertinggi) yaitu :

Jumlah skor kriterium $=$ Skor tertinggi $\mathrm{x}$ Jumlah responden

$$
\begin{aligned}
& =5 \times 91 \\
& =455
\end{aligned}
$$

Maka tingkat persetujuan terhadap metode itu : $(455: 455) \times 100 \%=100 \%$

Interval Kelas : Skor tertinggi : banyak kelas ( $455: 5=91)$

Skor $5 \times 91=455$

Skor 4 × $91=364$

Skor $3 \times 91=273$

Skor $2 \times 91=182$

Skor 1 × $91=91$

Secara kontinum dapat digambarkan seperti berikut :

Gambar 2. Interval Jawaban Responden

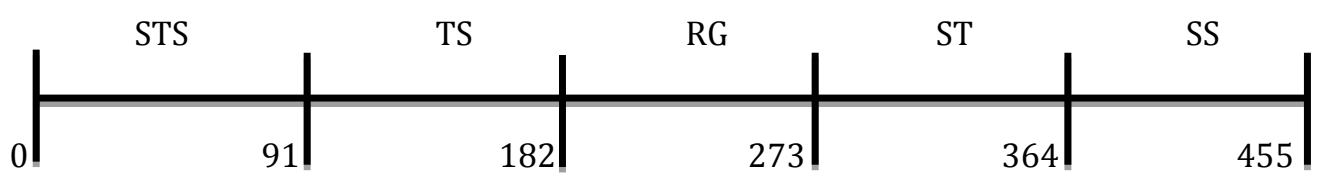

Sumber: Sugiyono, $2013: 141$

Nilai interval setiap kelas 91 maka dapat disusun kriteria setiap jawaban responden sebagai berikut :

Indikator jawaban
a. $\quad 0-91=$ Sangat tidak patuh
b. $91-182=$ Tidak patuh
c. $182-273=$ Kurang patuh
d. $273-364=$ Patuh
e. $364-455=$ Sangat patuh

\section{HASIL DAN PEMBAHASAN}

Hasil kuisioner yang diperoleh persepsi responden tentang faktor-faktor yang mempengaruhi kepatuhan wajib pajak bumi dan bangunan di Kelurahan Malabero Kecamatan Teluk Segara dengan indikator penelitian terdiri dari kesadaran wajib pajak, pengetahuan wajib pajak, kualitas pelayanan, tingkat penghasilan dan persepsi wajib pajak terhadap sanksi.

Secara rata-rata persepsi responden terhadap 5 (lima) faktor yang mem-pengaruhi kepatuhan wajib pajak PBB di kelurahan malabero kecamatan teluk segara terletak di daerah setuju. Artinya ke lima faktor tersebut hampir rata-rata membuat wajib pajak patuh. Secara rinci persepsi responden terhadap 5 (lima) faktor-faktor yang mempengaruhi kepatuhan wajib pajak bumi dan bangunan di Kelurahan Malabero Kecamatan Teluk Segara dapat dilihat pada tabel 10. 
Tabel 1. Hasil penelitian faktor-faktor yang mempengaruhi kepatuhan wajib pajak bumi dan bangunan

\begin{tabular}{|c|c|c|}
\hline \multirow{2}{*}{$\begin{array}{c}\text { No. } \\
1\end{array}$} & Indikator Kepatuhan & Total Skor \\
\hline & $\begin{array}{l}\text { Kesadaran Wajib Pajak } \\
\text { Kesadaran WP bahwa melakukan kepatuhan membayar PBB adalah suatu } \\
\text { kewajiban } \\
\text { WP sadar bahwa membayar pajak sudah membantu membangun pembangunan } \\
\text { nasional } \\
\text { WP segera membayar pajak setelah mendapatkan SPPT }\end{array}$ & 303 \\
\hline 2 & $\begin{array}{l}\text { Pengetahuan Wajib Pajak } \\
\text { SPPT PBB lunas termasuk merupakan salah satu syarat untuk pengajuan } \\
\text { pinjaman di Bank } \\
\text { Tata cara pembayaran PBB sangat sulit dilakukan } \\
\text { Pembayaran PBB adalah hal penting }\end{array}$ & $\begin{array}{l}367 \\
280 \\
300\end{array}$ \\
\hline 3 & $\begin{array}{l}\text { Kualitas Pelayanan } \\
\text { Penyampaian SPPT sudah sangat bagus disalurkan dari DPPKA ke kantor lurah } \\
\text { kemudian ketangan WP } \\
\text { Fasilitas untuk pembayaran PBB sudah sangat memadai } \\
\text { Pembayaran PBB sudah sangat dibuat sesederhana mungkin }\end{array}$ & $\begin{array}{l}194 \\
195 \\
\end{array}$ \\
\hline 4 & $\begin{array}{l}\text { Tingkat Penghasilan } \\
\text { Tidak mampu untuk membayar PBB sesuai dengan jumlah yang tertera di SPPT } \\
\text { menggunakan penghasilan anda. } \\
\text { Tidak mampu membayar PBB tepat pada waktu jatuh tempo pembayaran } \\
\text { Memiliki tunggakan kewajiban pajak karena tidak mampu membayar dengan } \\
\text { penghasilan }\end{array}$ & $\begin{array}{l}198 \\
171\end{array}$ \\
\hline 5 & $\begin{array}{l}\text { Persepsi Wajib Pajak Terhadap Sanksi } \\
\text { Anda mengerti sanksi jika tidak membayar PBB } \\
\text { Besarnya sanksi yang dikenakan telah sesuai } \\
\text { Petugas menjelaskan runcian tentang sanksi yang dikenakan oleh WP bila terjadi } \\
\text { keterlambatan dalam membayar WP }\end{array}$ & $\begin{array}{l}352 \\
313 \\
311\end{array}$ \\
\hline & Rata-Rata & 261 \\
\hline
\end{tabular}

Sumber : Data yang telah diolah

Dari tabel diatas indikator yang memperoleh skor tertinggi yaitu indikator SPPT PBB lunas termasuk merupakan salah satu syarat untuk pengajuan pinjaman di bank dengan skor 367 artinya indikator ini sangat mempengaruhi masyarakat dalam membayar PBB dengan alasan hanya untuk kepentingan pribadi, akan tetapi indikator ini bukan termasuk faktor-faktor yang mempengaruhi kepatuhan Wajib Pajak untuk membayar PBB. Kemudian indikator yang memperoleh skor terendah dengan skor sebesar 171 yaitu indikator memiliki tunggakan kewajiban pajak karena tidak mampu membayar menggunakan penghasilan artinya indikator ini tidak dapat mempengaruhi masyarakat dalam membayar PBB karena jumlah tagihan PBB relatif murah dan masih terjangkau bagi masyarakat untuk membayar tagihan PBB.

Hasil penelitian pada tabel 1 diatas menunjukkan bahwa secara rata-rata faktor-faktor yang mempengaruhi kepatuhan wajib pajak PBB di Kelurahan Malabero di Kecamatan Teluk Segara sebesar 261, skor ini terdapat di daerah kurang patuh artinya secara rata-rata faktor-faktor ini kurang dapat mempengaruhit wajib pajak agar patuh. Faktor-faktor yang sangat mempengaruhi kepatuhan wajib pajak PBB yaitu menurut persepsi responden adalah kesadaran wajib pajak, pengetahuan wajib pajak dan sanksi pajak. Sedangkan faktor kualitas pelayanan dan tingkat penghasilan menurut persepsi responden adalah faktor yang membuat wajib pajak kurang patuh terhadap membayar pajak bumi dan bangunan.

\section{KESIMPULAN}

1. Faktor dominan yang mempengaruhi kepatuhan wajib pajak bumi dan bangunan di Kelurahan Malabero Kecamatan Teluk Segara Kota Bengkulu adalah persepsi wajib pajak terhadap sanksi pajak dengan nilai rata-rata 325 dengan kriteria setuju, artinya hampir semua responden patuh terhadap sanksi pajak dan dapat mempengaruhi kepatuhan wajib pajak. Kemudian faktor dominan berikutnya yang mempengaruhi kepatuhan wajib pajak bumi dan bangunan yaitu faktor pengetahuan wajib pajak dengan rata-rata 315 dengan kriteria setuju, artinya hampir semua responden patuh terhadap faktor pengetahuan wajib pajak dapat mempengaruhi kepatuhan wajib pajak. Dan faktor dominan 
berikutnya yang mempengaruhi kepatuhan wajib pajak bumi dan bangunan yaitu faktor kesadaran wajib pajak dengan rata-rata 313 dengan kriteria setuju, artinya hampir semua responden patuh terhadap faktor kesadaran wajib pajak dapat mem-pengaruhi kepatuhan wajib pajak. Indikator yang memperoleh skor tertinggi yaitu indikator SPPT PBB lunas termasuk merupakan salah satu syarat untuk pengajuan pinjaman di bank artinya indikator ini sangat mempengaruhi masyarakat dalam membayar PBB dengan alasan hanya untuk kepentingan pribadi, akan tetapi indikator ini bukan termasuk faktor-faktor yang mempengaruhi kepatuhan Wajib Pajak untuk membayar PBB.

2. Faktor paling tidak dominan mempengaruhi kepatuhan wajib pajak bumi dan bangunan di Kelurahan Malabero Kecamatan Teluk Segara Kota Bengkulu adalah faktor kualitas pelayanan dengan rata-rata 196 dengan kriteria ragu-ragu, artinya semua responden kurang patuh terhadap faktor kualitas pelayanan dan tidak dapat mempengaruhi kepatuhan wajib pajak. Kemudian Faktor paling tidak dominan yang mempengaruhi kepatuhan wajib pajak bumi dan bangunan di Kelurahan Malabero Kecamatan Teluk Segara Kota Bengkulu adalah faktor tingkat penghasilan dengan rata-rata 190 dengan kriteria tidak setuju, artinya semua responden kurang patuh terhadap faktor tingkat penghasilandan tidak dapat mempengaruhi kepatuhan wajib pajak. Dan indikator yang memperoleh skor terendah yaitu indikator memiliki tunggakan kewajiban pajak karena tidak mampu membayar menggunakan penghasilan artinya indikator ini tidak dapat mempengaruhi masyarakat dalam membayar PBB karena jumlah tagihan PBB relatif murah dan masih terjangkau bagi masyarakat untuk membayar tagihan PBB.

\section{Saran}

Kepada petugas DPPKA (Dinas Pendapatan Pengelolaan Keuangan dan Aset) hendaknya lebih memperhatikan faktor kualitas pelayanan dengan peningkatan kualitas sarana dan prasarana Kantor DPPKA (Dinas Pendapatan Pengelolaan Keuangan dan Aset) agar wajib pajak lebih dipermudah dan lebih nyaman dalam membayar dan mengurus Pajak Bumi dan Bangunan. Serta dapat lebih meningkatkan kepatuhan wajib pajak agar Pajak Bumi dan Bangunan dapat dibayar tepat waktu dengan penyuluhan rutin serta memperketat sanksi.

\section{DAFTAR PUSTAKA}

Agus, S. 2006. Perpajakan Bendaharawan Pemerintah. Rajawali Pers. Jakarta.

Diana, S. 2013. Konsep Dasr Perpajakan. PT. Refika Aditama. Bandung.

Fidel. 2010. Cara Mudah \& Praktis Memahami Masalah- masalah Perpajakan. PT Raja Grafindo Persada. Jakarta.

Mardiasmo. 2006. Per pajakan, Edisi Revisi 2006. CV. ANDI OFFSET. Yogyakarta.

Nurmantu, Safri, 2010. Pengantar Ilmu Perpajakan. Grant. Jakarta.

Pandiangan. 2014. Administrasi Perpajakan. Penerbit Erlangga. Jakarta.

Rizka. 2014. Perpajakan.studentjournal.ub.ac.id. Jurnal Perpajakan Vol. 3 No. 1 November 2014.

Sugiyono. 2013. Metodologi Penelitian Kuantitatif, Kualitatif Dan R\&D. ALFABETA. Bandung

Undang-undang Republik Indonesia Nomor 28 Tahun 2009. Tentang Pajak Daerah Dan Retribusi Daerah. SL Media. Jakarta.

Widyaningsih, Aristanti. 2013. Hukum Pajak dan Perpajakan. ALFABETA. Bandung.

Wirawan, I,B. 2008. Hukum Pajak, Edisi Empat. Salemba Empat. Jakarta.

Yusnindar, Johan, 2015. Perpajakan.studentjournal.ub.ac.id. Jurnal Perpajakan (JEJAK) Vol. 1 No. 1 Januari 2015. 